Prepared in Cooperation with the U.S. Bureau of Land Management

\title{
Site-Characteristic and Hydrologic Data for Selected Wells and Springs on Federal Land in Clark County, Nevada
}

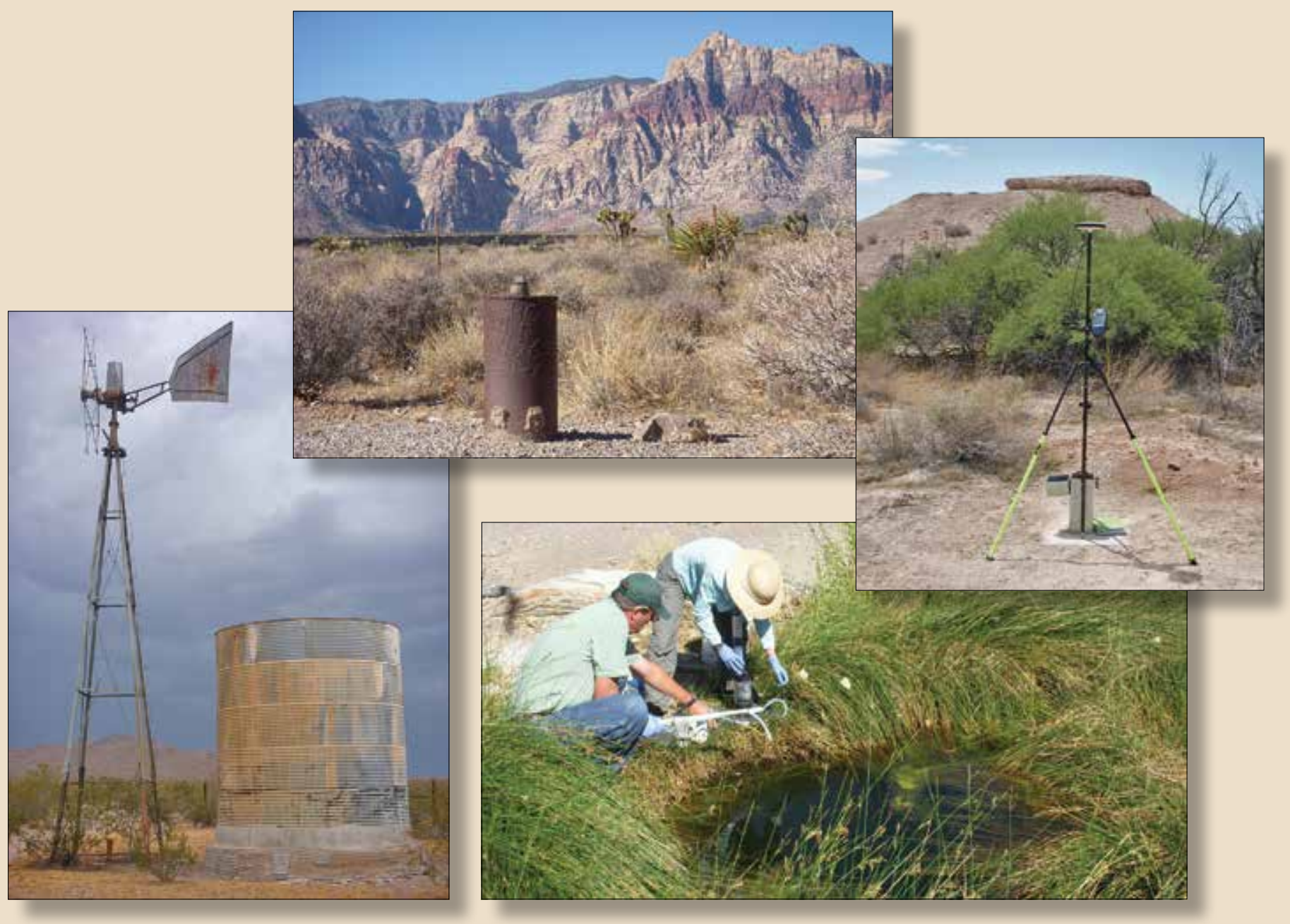

Data Series 864 


\section{Cover photographs, clockwise from the top:}

Abandoned Red Rock Wash Well (site 360809115252601). Photo by Michael Pavelko.

Collecting global positioning system data at Stump Spring Well (site 355941115490901). Photo by Jon Darnell.

Collecting water samples at Cactus Spring (site 363436115432201). Photo by Michael Pavelko. Windmill and water tank at abandoned Deep Well (site 352217114511401). Photo by Michael Pavelko. 


\section{Site-Characteristic and Hydrologic Data for Selected Wells and Springs on Federal Land in Clark County, Nevada}

By Michael T. Pavelko

Prepared in Cooperation with the U.S. Bureau of Land Management

Data Series 864 


\title{
U.S. Department of the Interior SALLY JEWELL, Secretary
}

\section{U.S. Geological Survey Suzette M. Kimball, Acting Director}

\author{
U.S. Geological Survey, Reston, Virginia: 2014
}

For more information on the USGS - the Federal source for science about the Earth, its natural and living resources, natural hazards, and the environment, visit http://WwW.usgs.gov or call 1-888-ASK-USGS

For an overview of USGS information products, including maps, imagery, and publications, visit http://Www.usgs.gov/pubprod.

To order this and other USGS information products, visit http://store.usgs.gov.

Any use of trade, firm, or product names is for descriptive purposes only and does not imply endorsement by the U.S. Government.

Although this information product, for the most part, is in the public domain, it also may contain copyrighted materials as noted in the text. Permission to reproduce copyrighted items must be secured from the copyright owner.

Suggested citation:

Pavelko, M.T., 2014, Site-characteristic and hydrologic data for selected wells and springs on Federal land in Clark County, Nevada: U.S. Geological Survey Data Series 864, 18 p. http://dx.doi.org/10.3133/ds864

ISSN 2327-638X (online) 


\section{Contents}

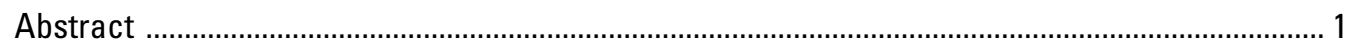

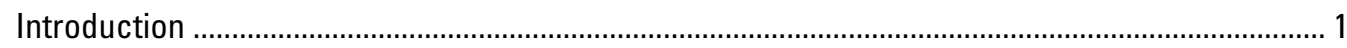

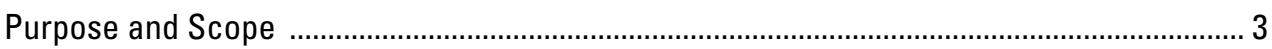

National Water Information System ......................................................................................... 3

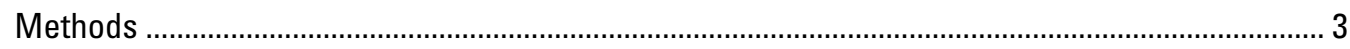

Site-Characteristic Data Review and Collection ...................................................................... 5

Hydrologic Data Review and Collection ................................................................................ 7

Site-Characteristic and Hydrologic Data .................................................................................... 7

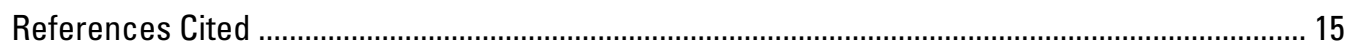

Appendix 1. Selected data stored in the U.S. Geological Survey National Water Information

System for selected wells and springs on Federal land in Clark County, Nevada ............ 17

Appendix 2. Publications reviewed for site-characteristic and hydrologic data for selected wells and springs on Federal land in Clark County, Nevada ...................................................... 17

\section{Figures}

1. Map showing location of selected wells and springs on Federal land in Clark County, Nevada 2

2. Schematic diagram showing components of the National Water Information System ...... 3

\section{Tables}

1. Data fields in the National Water Information System Sitefile reviewed and updated for selected wells and springs on Federal land in Clark County, Nevada ......................... 4

2. Groundwater Site Inventory data tables reviewed and updated for selected wells and springs on Federal land in Clark County, Nevada ...................................................... 5

3. National Water Information System site-characteristic data determined from a geographic information system for selected wells and springs on Federal land in Clark County, Nevada

4. National Water Information System wells and springs on Federal land in Clark County, Nevada, surveyed by the U.S. Geological Survey with a global positioning system, 2007-2010

5. National Water Information System wells and springs on Federal land in Clark County, Nevada, for which water samples were collected and analyzed by the U.S. Geological Survey for this and other Southern Nevada Public Land Management Act projects, 2007-2010 


\section{Conversion Factors and Datums}

Inch/Pound to SI

\begin{tabular}{|c|c|c|}
\hline Multiply & By & To obtain \\
\hline \multicolumn{3}{|c|}{ Length } \\
\hline inch (in) & 2.54 & centimeter $(\mathrm{cm})$ \\
\hline foot $(\mathrm{ft})$ & 0.3048 & meter $(\mathrm{m})$ \\
\hline \multicolumn{3}{|c|}{ Area } \\
\hline square mile $\left(\mathrm{mi}^{2}\right)$ & 2.590 & square kilometer $\left(\mathrm{km}^{2}\right)$ \\
\hline
\end{tabular}

Temperature in degrees Fahrenheit $\left({ }^{\circ} \mathrm{F}\right)$ may be converted to degrees Celsius $\left({ }^{\circ} \mathrm{C}\right)$ as follows:

${ }^{\circ} \mathrm{C}=\left({ }^{\circ} \mathrm{F}-32\right) / 1.8$

Vertical coordinate information is referenced to the National Geodetic Vertical Datum of 1929

(NGVD 29).

Horizontal coordinate information is referenced to the North American Datum of 1983 (NAD 83).

GPS data were collected and referenced to the World Geodetic System of 1984 (WGS 84) and converted to NAD 83 for National Water Information System purposes.

\section{Abbreviations and Acronyms}

$\begin{array}{ll}\text { ADAPS } & \text { Automated Data-Processing System } \\ \text { BLM } & \text { U.S. Bureau of Land Management } \\ \text { DRI } & \text { University of Nevada Desert Research Institute } \\ \text { FWS } & \text { U.S. Fish and Wildlife Service } \\ \text { GIS } & \text { geographic information system } \\ \text { GPS } & \text { global positioning system } \\ \text { GWSI } & \text { Groundwater Site Inventory } \\ \text { MGPS } & \text { mapping-grade GPS } \\ \text { NDWR } & \text { Nevada Division of Water Resources } \\ \text { NHD } & \text { National Hydrography Dataset } \\ \text { NPS } & \text { National Park Service } \\ \text { NWIS } & \text { National Water Information System } \\ \text { NWISWeb } & \text { NWIS web interface } \\ \text { PLSS } & \text { Public Land Survey System } \\ \text { QWDATA } & \text { Water-Quality System } \\ \text { RGPS } & \text { recreational-grade GPS } \\ \text { SGPS } & \text { survey-grade GPS } \\ \text { SNPLMA } & \text { Southern Nevada Public Lands Management Act } \\ \text { USFS } & \text { U.S. Forest Service } \\ \text { USGS } & \text { U.S. Geological Survey } \\ \text { WUDS } & \text { Water-Use Data System }\end{array}$




\title{
Site-Characteristic and Hydrologic Data for Selected Wells and Springs on Federal Land in Clark County, Nevada
}

\author{
By Michael T. Pavelko
}

\begin{abstract}
Site-characteristic and hydrologic data for selected wells and springs on U.S. Bureau of Land Management, National Park Service, U.S. Fish and Wildlife Service, and U.S. Forest Service land in Clark County, Nevada, were updated in the U.S. Geological Survey's National Water Information System (NWIS) to facilitate multi-agency research. Data were researched and reviewed, sites were visited, and NWIS data were updated for 231 wells and 198 springs, including 36 wells and 67 springs that were added to NWIS and 44 duplicate sites that were deleted. The site-characteristic and hydrologic data collected, reviewed, edited, and added to NWIS include locations, well water levels, spring discharges, and water chemistry. Site-characteristic and hydrologic data can be accessed from links to the NWIS web interface; data not available through the web interface are presented in appendixes to this report.
\end{abstract}

\section{Introduction}

Clark County, the southernmost county in Nevada (fig. 1), encompasses about 8,100 square miles and lies within the Great Basin and Sonoran Desert sections of the Basin and Range Physiographic Province (Fenneman and Johnson, 1946). In Clark County, altitudes range from about 480 to 11,920 feet (ft) above sea level, air temperatures range from about 20 to 120 degrees Fahrenheit, and annual precipitation ranges from about 3 to 20 inches. The large ranges of altitudes, air temperatures, and precipitation have resulted in diverse ecosystems, from barren desert playas to ponderosa pine forests, and diverse species, including the desert tortoise, bristlecone pine, Moapa dace, bald eagle, and bighorn sheep.

The population of Clark County, which includes Las Vegas, increased from 741,459 in 1990 to 1,375,765 in 2000 then to 1,951,269 in 2010 (U.S. Census Bureau, 2013). To meet the land-use demands of the growing population, the Southern Nevada Public Lands Management Act (SNPLMA) was passed in 1998 to allow "the Bureau of Land Management (BLM) to sell public land within a specific boundary around Las Vegas, Nevada. The revenue derived from land sales is split among the State of Nevada General Education Fund ( 5 percent), the Southern Nevada Water Authority (10 percent), and a special account available to the Secretary of the Interior for" parks, trails, natural areas, conservation initiatives, capital improvements, and a multi-species habitat conservation plan, among other land-management goals (U.S. Bureau of Land Management, 2013a). A portion of the funds generated by land sales is available to the BLM, National Park Service (NPS), U.S. Fish and Wildlife Service (FWS), and U.S. Forest Service (USFS); combined, the agencies manage more than 85 percent of the land in Clark County (fig. 1)

The growing population and increasing demands on water resources, combined with the possible effects of climate change, have prompted local- and regional-scale hydrologic studies. A recurring impediment for cross-agency and regional hydrologic studies, including those in support of the conservation initiatives, capital improvements, and habitat conservation plans outlined in SNPLMA, has been the lack of a comprehensive and consistent hydrologic database that can be accessed by multiple agencies. The U.S. Geological Survey's (USGS) National Water Information System (NWIS) was identified as an existing and comprehensive hydrologic database that provides a consistent data structure for wells and springs, and much of the hydrologic data are accessible from the NWIS web interface (NWISWeb; U.S. Geological Survey, 2013b).

Data stored in NWIS are collected for a wide variety of studies over many decades and represent a combination of data collected by the USGS and Federal, state, and local agencies; well drillers; and private and public organizations. Consequently, the consistency and detail of NWIS data can be variable and may not be up to date. To provide the agencies and public with updated and more consistent data, the BLM entered into a cooperative agreement with the USGS to: (1) review and update site-characteristic and hydrologic data stored in NWIS for selected wells and springs on land managed by the BLM, NPS, FWS, and USFS in Clark County, Nevada; (2) improve latitude, longitude, and altitude data with global positioning system (GPS) surveys; and (3) collect and analyze water samples from selected sites. Data were collected for this project from July 1, 2007, to June 30, 2013. 


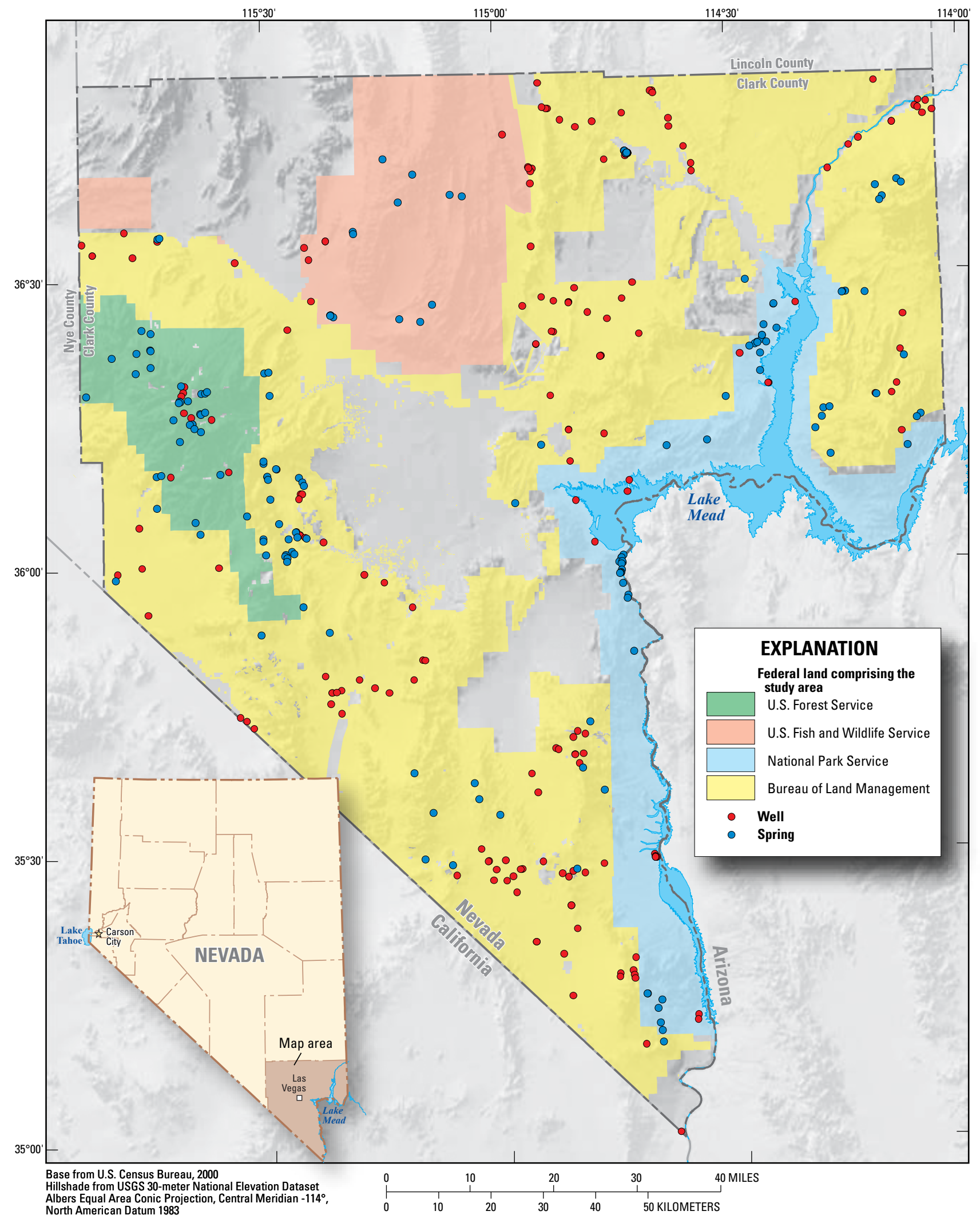

Figure 1. Location of selected wells and springs on Federal land in Clark County, Nevada. 


\section{Purpose and Scope}

This report presents site-characteristic and hydrologic data for selected wells and springs on Federal land in Clark County, Nevada, up to June 30,2013. All data within the report are stored in NWIS; methods used to update NWIS for this project are presented. Site-characteristic and hydrologic data can be accessed from NWISWeb using provided links (appendix 1-1). Data stored in NWIS that are not accessible from NWISWeb and publications and reports reviewed for this project are presented in appendixes. Data requests and inquiries about the data in this report or about NWIS can be directed to the USGS Nevada Water Science Center.

\section{National Water Information System}

The national repository for water-resources data is NWIS, which is a distributed database storing various types of data across multiple USGS Water Science Centers. Data for more than 1.5 million sites are stored and disseminated through NWISWeb to provide reliable water-resources data to resource-management agencies and the public. Hydrologic data stored in NWIS were collected and analyzed according to USGS data-collection guidelines and analytical methods (Buchanan and Somers, 1969; Cunningham and Schalk, 2011; Rantz and others, 1982; U.S. Geological Survey, variously dated).

Data in NWIS are stored in four primary subsystems that are linked to NWIS Sitefiles (fig. 2). Every site in NWIS ha a Sitefile that primarily contains location information and other site-characteristic data, including the agency and site identification numbe, which are the composite keys used to relate site data to the NWIS subsystems (fig. 2; table 1). The Groundwater Site Inventory (GWSI) subsystem contains sitecharacteristic, discharge, and water-level data (table 2), however discharge data stored in GWSI are not accessible from NWISWeb. The Automated Data-Processing System (ADAPS) contains periodic water-level and discharge measurements and time series data collected from automated recording equipment, such as water-level, discharge, and water-chemistry data; discharge data stored in ADAPS are accessible from NWISWeb. The Water-Quality System (QWDATA) contains water-chemistry data. The Water-Use Data System (WUDS), which was not reviewed for this project, contains aggregated and site-specific wate -use (withdrawal) data.

Data accessible from NWISWeb for this report are: (1) selected site-characteristic data stored in the Sitefile (table 1); (2) well water levels stored in GWSI; (3) spring- and streamdischarge data stored in ADAPS; and (4) water-chemistry data stored in QWDATA. Additional information about NWIS can be found in USGS Fact Sheet FS-027-98, which provides links to additional resources (U.S. Geological Survey, 1998).

\section{Methods}

Project-area wells and springs documented in NWIS were researched and visited to document current conditions, verify or update existing site-characteristic and hydrologic data, and collect new data. For this project, site-characteristic data include general-description, location, geohydrologic, and well-construction data. Hydrologic data consist of well water levels, well and spring discharge, and water-chemistry data. Site-characteristic and hydrologic data for NWIS sites within the project area were compared to published or reported data (appendix 2-1) and Nevada Division of Water Resources (NDWR) well logs. Sites identified as duplicates were deleted from NWIS.

Sites in NWIS initially were reviewed and submitted to the BLM, NPS, FWS, and USFS to determine whether additional wells or springs should be added. Sites were visited from July 1, 2007, to June 30, 2013, to collect, verify, and update site-characteristic and hydrologic data. Hydrologic data were collected for the project according to USGS guidelines and

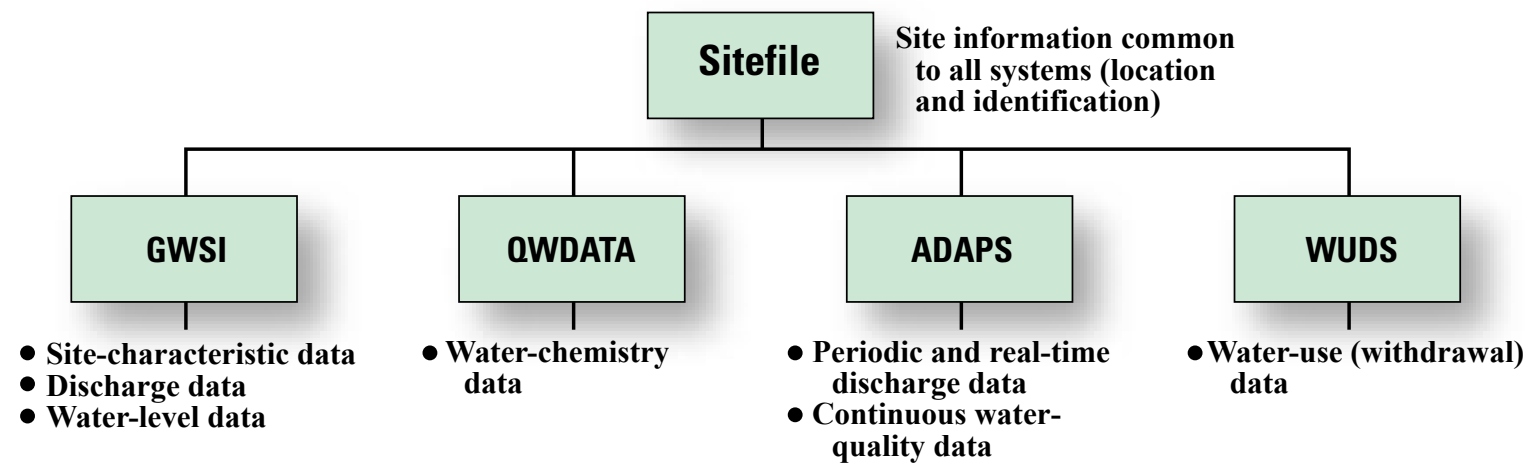

GWSI: Groundwater Site Inventory QWDATA: Water-Quality System ADAPS: Automated Data-Processing System WUDS: Water-Use Data System

Figure 2. Components of the National Water Information System. 
Table 1. Data fields in the National Water Information System Sitefile reviewed and updated for selected wells and springs on Federal land in Clark County, Nevada.

[NWIS, National Water Information System; NWISWeb, web interface for NWIS; USGS, U.S. Geological Survey]

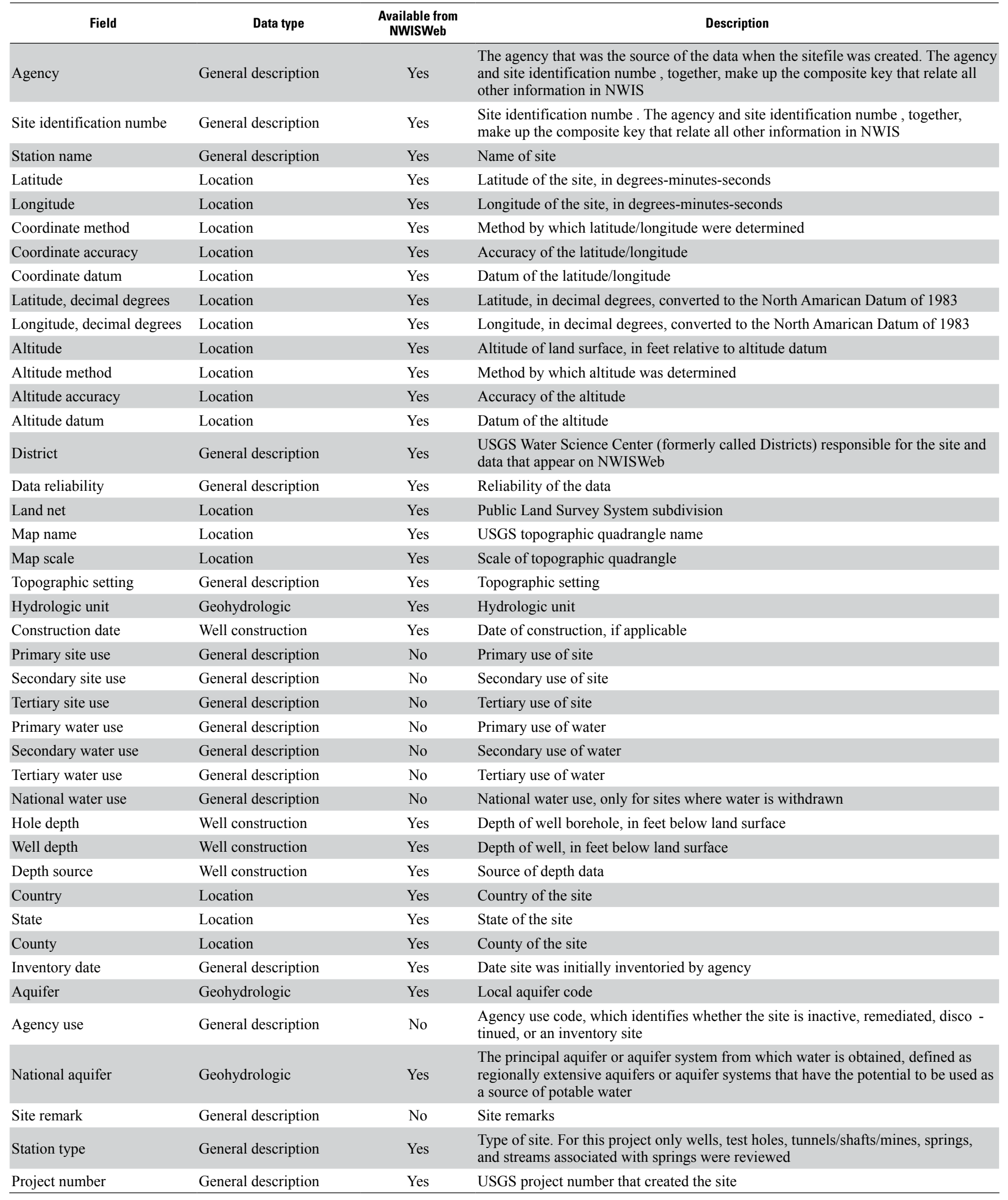


Table 2. Groundwater Site Inventory data tables reviewed and updated for selected wells and springs on Federal land in Clark County, Nevada.

[NDWR, Nevada Division of Water Resources]

\begin{tabular}{|c|c|c|c|}
\hline Data table & Data type & $\begin{array}{l}\text { Data available from } \\
\text { NDWR well log }\end{array}$ & Description \\
\hline Construction & Construction & Yes & $\begin{array}{l}\text { Stores general construction information about the well, including date drilled, driller, and } \\
\text { drilling methods }\end{array}$ \\
\hline Borehole & Construction & Yes & Stores depth-specific well borehole diameter dat \\
\hline Casing & Construction & Yes & Stores depth-specific well casing material, diamete, and thickness \\
\hline Open interval & Construction & Yes & Stores depth-specific well casing open-interval data, including type and size of opening \\
\hline Measuring point & Construction & No & $\begin{array}{l}\text { Stores information about the measuring point of a well, including a description and height } \\
\text { of the measuring point and the dates the measuring point was used if the measuring point } \\
\text { changed over time }\end{array}$ \\
\hline Water level & Hydrologic & Yes & Stores well water-level data including date, method, and accuracy \\
\hline Lift & Construction & No & $\begin{array}{l}\text { Stores information about the type of device used to remove water from a well, if any, and } \\
\text { includes the dates that device was used }\end{array}$ \\
\hline Geohydrology & Geohydrologic & Yes & $\begin{array}{l}\text { Stores lithologic and geohydrologic units. For wells these data are depth specific and for } \\
\text { springs these data can describe the surface geology or the geologic unit from which the water } \\
\text { originates at depth }\end{array}$ \\
\hline Geophysical logs & Geohydrologic & Yes & Stores the depths and types of geophysical logs for a well, including NDWR well logs \\
\hline Discharge & Geohydrologic & Yes & $\begin{array}{l}\text { Stores well discharge data, including discharge rate, discharge duration, and water-level } \\
\text { drawdown resulting from the discharge. This table automatically calculates the specific } \\
\text { capacity of a well if the discharge is positive, static and production water levels are provided, } \\
\text { and static water level is higher then production water level }\end{array}$ \\
\hline Spring & Geohydrologic & No & $\begin{array}{l}\text { Stores spring name, type, permanance, number of openings, improvements, sphere of dis- } \\
\text { charge, and variability of discharge }\end{array}$ \\
\hline Site visit & General description & No & Stores date and personnel of site visits \\
\hline Remarks & General description & No & $\begin{array}{l}\text { Stores general remarks about a site, such as site status and current conditions, and includes a } \\
\text { date fiel }\end{array}$ \\
\hline Other data & General description & No & $\begin{array}{l}\text { Stores information about other data that are available for sites. For project sites, this table } \\
\text { primarily was used to store references to publications with data or information about sites }\end{array}$ \\
\hline Miscellaneous values & $\begin{array}{l}\text { General description; } \\
\text { location }\end{array}$ & No & $\begin{array}{l}\text { Stores miscellaneous values. For sites in Clark County this table primarily is used to identify } \\
\text { the hydrographic area (Rush, 1968; Cardinalli and others, 1968) of a site }\end{array}$ \\
\hline Other identifie & $\begin{array}{l}\text { General description; } \\
\text { location }\end{array}$ & Yes & $\begin{array}{l}\text { Stores alternate names or identifiers for a site, such as names used by other agencies and } \\
\text { names used in published reports. For project sites, this data table also is used to store NDWR } \\
\text { well-log and permit numbers and the groundwater flow system and subbasin (Harrill and } \\
\text { others, } 1988 \text { and Laczniak and others, 1996) }\end{array}$ \\
\hline
\end{tabular}

policies (Cunningham and Schalk, 2011; Rantz and others, 1982; U.S. Geological Survey, variously dated). For this project, wells are defined as NWIS sites that have a Sitefile Statio Type of well, test hole not completed as a well, or tunnel, shaft, or mine. Springs are defined as NWIS sites that have a Sitefile Station Type of spring or stream, but only include streams that are associated with spring discharge (table 1, appendixes 1-1 and 1-2).

After a site visit, observed site-characteristic data were compared to NWIS, which was updated as needed, and measured hydrologic data were added to NWIS. When observed conditions differed from reported values, edits were made in NWIS and a descriptive comment was added to the GWSI Remarks data table (table 2; appendix 1-14). Published data for the project mainly came from USGS, NDWR, and University of Nevada Desert Research Institute (DRI) reports (appendix 2-1); additional data were obtained from NDWR well logs. Published hydrologic data that have documented collection methods meeting USGS data-collection guidelines were added to NWIS and an abbreviated citation was added to the GWSI Other Data data table (table 2; appendix 1-15).
Published hydrologic data that do not have documented collection methods or were collected with methods not meeting USGS data-collection guidelines (Cunningham and Schalk, 2011; Rantz and others, 1982; U.S. Geological Survey, variously dated) were not added to NWIS. For publications with undocumented data-collection methods or data-collection methods that do not meet USGS guidelines, an abbreviated citation was added to the GWSI Other Data data table and, when appropriate, descriptive comments describing the citation and data were added to the GWSI Remarks data table. For example, sample-filtration procedures are not documented for water-chemistry data reported in McKinley and others (1991), so the data were not added to QWDATA but remarks were added to the GWSI Remarks data table that reference the report and sampling dates for the sampled sites.

\section{Site-Characteristic Data Review and Collection}

Site-characteristic data reviewed for this project were general-description, well-construction, geohydrologic, and location data (tables 1, 2; appendixes 1-2-1-17). 
General-description data include names and other identifiers, station type, site and water use, and other information that describes a well or spring. Well-construction data include drill dates, depth, measuring point, and pump information, and borehole, casing, and open-interval dimensions and information. Geohydrologic data include information regarding regional and national aquifers and hydrologic units, borehole lithology, geophysical logs, well discharge, and springs. Location data include latitude, longitude, and altitude values and other location-based information.

Site-characteristic data reviewed for this project primarily are from published reports (appendix 2-1), NDWR well $\operatorname{logs}$, and site visits. A well log must be submitted to NDWR, according to Nevada Revised Statute 534.170, when a well is drilled, reconditioned, or plugged in Nevada. The well logs, available from the NDWR on-line well-log database (Nevada Division of Water Resources, 2013), provide information about the drilling and completion of wells and include sitecharacteristic (table 2) and hydrologic data. Site-characteristic data verified or collected during site visits include: (1) latitude, longitude, related location data, and topographic setting; (2) above-ground well casing diameter, thickness, and material; (3) well measuring-point height and description; (4) spring attributes and description; (5) site status and current conditions; and (6) site visit information.

Location data were reviewed for project-area sites and updated where appropriate. Initially, 195 wells and 131 springs within the project area were documented in NWIS. Of those sites, 24 duplicate wells and 20 duplicate springs were deleted. Twenty-one wells and 2 springs had incorrect latitude and longitude values stored in NWIS; when the values were updated, the wells and springs were not located on Federal lands.

Location data collected during site visits were latitude, longitude, and altitude. Values and associated meta-data such as datum, method, and accuracy of measurements are stored in the Sitefile (table 1). Other location-based information was determined from a geographic information system (GIS; table 3). GIS-derived data, including county, state, country, Public Land Survey System (PLSS) subdivision (U.S. Bureau of Land Management, 2013b), hydrologic unit, aquifer, national aquifer, and USGS 1:24,000-scale topographic quadrangle name, are stored in the Sitefile. The hydrographic area of a site (Rush, 1968; Cardinalli and others, 1968) is stored in the GWSI Miscellaneous Values data table, and the groundwater flow system and subbasin of a site (Harrill and others, 1988; Laczniak and others, 1996) are stored in the GWSI Other Identifier data table (table 2)

Latitude, longitude, and altitude data were collected with recreational-grade, mapping-grade, or survey-grade GPS devices. Recreational-grade GPS (RGPS) surveys resulted in latitude and longitude values accurate to about one-third of a second, or about $35 \mathrm{ft}$. Altitude values from RGPS surveys were not used; instead, altitude values were derived from 1:24,000-scale topographic quadrangles, for which altitude values have an accuracy equivalent to one-half of the topographic contour interval. Contour intervals for 1:24,000-scale topographic quadrangles in the project area range from $3 \mathrm{ft}$ (1 meter $[\mathrm{m}])$ to $40 \mathrm{ft}$ (12 m). Mapping-grade GPS (MGPS) surveys resulted in latitude and longitude values accurate to about one-hundredth of a second, or about 1 foot, and altitude values accurate to about 1 foot. Survey-grade GPS (SGPS) surveys resulted in latitude and longitude values accurate to about one-hundredth of a second, or about 1 foot, and altitude values ranging in accuracy from 0.1 foot to 1 foot. All GPS latitude and longitude values were referenced to the World Geodetic System of 1984 and were converted to North American Datum of 1983 for entry into NWIS. Altitude values from SGPS and MGPS were referenced to the North American Vertical Datum of 1988. Altitudes were interpolated from USGS 1:24,000-scale topographic quadrangles for sites for which latitude and longitude data were updated from PLSS locations, Esri digital imagery (Esri, 2013), reported values, NHD values, or USGS 1:24,000-scale topographic quadrangles.

Some NWIS sites initially could not be found in the field so additional location information was researched. Additional location information included reported latitude and longitude values from USGS reports, the National Hydrography Dataset (NHD; U.S. Geological Survey, 2013a), and Esri digital

Table 3. National Water Information System site-characteristic data determined from a geographic information system for selected wells and springs on Federal land in Clark County, Nevada.

\begin{tabular}{|c|c|c|}
\hline Site characteristic & Data table & Reference or source \\
\hline County, state, and country & Sitefil & U.S. Census Bureau, 2007 \\
\hline Public Land Survey System subdivision (land net) & Sitefil & U.S. Bureau of Land Management, 2013c \\
\hline Hydrologic unit & Sitefil & Steeves and Nebert, 1994 \\
\hline Aquifer & Sitefil & Crafford, 2007 \\
\hline National aquifer & Sitefil & U.S. Geological Survey, 2005 \\
\hline Map name & Sitefil & Esri, 2008 \\
\hline Hydrographic area $^{1}$ & Miscellaneous values & Peltz and others, 2005 \\
\hline Groundwater flow system and subbasi & Other identifie & Harrill and others, 1988; Laczniak and others, 1996 \\
\hline
\end{tabular}


imagery (Esri, 2013) and reported PLSS subdivisions from USGS reports, NDWR well logs, and NDWR Reconnaissance Reports. If the site could not be found using additional location information, NWIS latitude and longitude values either were left alone or were changed to reflect a reported location and a comment was added to the GWSI Remarks data table (table 2, appendix 1-14). For example, there is no well at the previous NWIS location for site 354724115163501 (165 S25 E60 08A 1 WELL (REPORT R46)) or at the PLSS Section 8AA of Township 25 South, Range 60 East, which is the reported location from the NDWR well log and Glancy (1968). Since the well could not be found, the latitude and longitude values stored in the NWIS Sitefile were adjusted to coincide with the reported PLSS location and comments were added to the GWSI Remarks data table that explain there is no well at the location, that the well could not be found, and that the coordinates were adjusted to coincide with the location documented on the well $\log$ (table 2, appendix 1-14).

\section{Hydrologic Data Review and Collection}

Hydrologic data reviewed or collected for this project were well water levels, spring discharges, and water-chemistry data. Well water levels measured for this project, documented in NDWR well logs, or published in reports were entered into the GWSI Water Level data table (table 2). Water levels collected for this project were measured with calibrated electronic tapes or steel tapes following USGS guidelines (Cunningham and Schalk, 2011). Spring discharges measured by the USGS and published discharge data with documented methods that meet USGS guidelines were entered into ADAPS. Spring discharges were measured volumetrically for this project. Water-chemistry data reviewed or collected for this project were entered into QWDATA. For this project, water samples were collected from sites selected by USGS and BLM personnel based on spatial and temporal gaps in water-chemistry data. For selected sites, field characteristics were measured and samples were collected. The samples were analyzed for major anions and cations, trace metals, nutrients, and isotopes; not every sampled site was analyzed for the same constituents. The water-chemistry data were analyzed at the USGS National Water-Quality Laboratory and the USGS Reston Stable Isotope Lab and are available from NWISWeb.

\section{Site-Characteristic and Hydrologic Data}

Site-characteristic and hydrologic data were researched, reviewed, and collected for 186 wells and 176 springs on Federal land in Clark County, Nevada (fig. 1), inlcuding 36 wells and 67 springs added for this project. Site-characteristic data for project sites are stored in NWIS Sitefiles (table 1, appendix 1-2) and GWSI Construction, Borehole, Casing,
Open Interval, Measuring Point, Lift, Geohydrology, Geophysical Logs, Discharge, Spring, Visit, Remarks, Other Data, Miscellaneous Values, and Other Identifier data tables (table 2, appendixes 1-3-1-17). Hydrologic data for project sites are stored in GWSI Water Level data tables, ADAPS (springdischarge data), and QWDATA (water-chemistry data) and are accessible from NWISWeb using the links presented in appendix 1-1.

Location data, which includes latitude, longitude, and altitude values, horizontal and vertical datums, data-collection methods, and data-accuracy values, were updated in NWIS Sitefiles (table 1) for 129 wells and 141 springs. The USGS collected SGPS data for 13 wells and 2 springs, MGPS data for 9 wells and 18 springs, and RGPS data for 75 wells and 97 springs (table 4); the BLM collected RGPS data for 1 well and 1 spring. Latitude and longitude data were updated with published values for 1 well and 5 springs and with NHD values for 5 springs. Latitude and longitude data were estimated from reported PLSS locations for 19 wells and 1 spring, from Esri digital imagery (Esri, 2013) for 10 wells and 8 springs, and from USGS 1:24,000-scale topographic quadrangles for 1 well and 3 springs.

Historic and current water levels from 2,372 measurements made at 128 wells in the project area were added to GWSI. The water levels added to GWSI consist of 1,780 water levels measured by other agencies for 33 wells, 537 measured by the USGS for 89 wells, 52 measured by 52 well drillers, 1 measured by an unknown source for 1 well, 1 measured by 1 well owner, and 1 reported for 1 well. Of the 2,372 water levels added to NWIS for this project, 1,026 were measured at 73 wells from July 1, 2007, to June 30, 2013. The measured water levels consist of 377 measured by the USGS for 57 wells for this and other USGS projects, 644 measured by other agencies for 25 wells, and 5 measured by well drillers.

Historic and current spring discharges from 1,419 measurements made at 71 springs in the project area were added to ADAPS. The discharge values added to ADAPS consist of 334 values measured at 21 springs by the USGS for this and other USGS projects between July 1, 2007, and June 30, 2013, and 1,085 published values measured at 70 springs primarily by USGS, NDWR, and DRI personnel.

Water-chemistry data for 194 samples from 21 wells and 67 springs in the project area were added to QWDATA. The data include analytical results for 124 samples from 15 wells and 39 springs collected by the USGS for this and other SNPLMA projects from July 1, 2007, to June 30, 2013 (table 5) and published data for 70 samples from 7 wells and 38 springs. For SNPLMA projects, field parameters were measured and samples were analyzed for major anions and cations, trace metals, nutrients, and isotopes. 
Table 4. National Water Information System wells and springs on Federal land in Clark County, Nevada, surveyed by the U.S. Geological Survey (USGS) with a global positioning system, 2007-2010.

[Sites with latitude and longitude values from a recreational-grade global positioning system (GPS) survey had altitudes updated from USGS 1:24,000-scale topographic quadrangles]

\begin{tabular}{|c|c|c|}
\hline Site identification number & Station name & Grade of GPS device \\
\hline 363422115433701 & 161 S16 E55H11DAAC1 Cactus Springs 3 & Survey \\
\hline 363436115432201 & 161 S16 E55H12BCAB1 CACTUS SPRING & Mapping \\
\hline 362450115442001 & 161 S18 E55 01DACC1 COLD CREEK SPRING & Mapping \\
\hline 362500115464701 & 161 S18 E55 02ACAD1 WILLOW SPRING & Mapping \\
\hline 362258115444501 & 161 S18 E55 13DBDD1 WHISKY SPRING & Recreational \\
\hline 362254115444001 & 161 S18 E55 13DDBC1 MCFARLAND SPRING & Recreational \\
\hline 362211115494101 & 162 S18 E55 20CACB1 WHEELER WELL & Recreational \\
\hline 362238115462801 & 162 S18 E55 23BBAD1 TROUGH SPRING & Recreational \\
\hline 362108115444201 & 162 S18 E55 25DDCB1 WOOD SPRING & Recreational \\
\hline 362033115463201 & 162 S18 E55 35CBBD1 BUCK SPRING & Recreational \\
\hline 361541115415001 & 162 S19 E56 28DCCD1 PEAK SPRING & Mapping \\
\hline 390949115440101 & 162 S20 E56 31CDAA1 & Recreational \\
\hline 360956115432801 & 162 S20 E56 31DADA1 KIUP SPRING & Recreational \\
\hline 360946115421401 & 162 S20 E56 33CCAA1 TROUT CANYON 01 & Mapping \\
\hline 360429115462101 & 162 S21 E55 35CDBC1 USBLM NDOT 02 & Recreational \\
\hline 360459115391101 & 162 S21 E56 36BCBB1 LOST CABIN SPRING & Recreational \\
\hline 360536115323401 & 162 S21 E57 25CBAC1 SOUTH SPRING & Recreational \\
\hline 360017115460401 & 162 S22 E55 26DBCA1 JEEP TRAIL & Mapping \\
\hline 355941115490901 & 162 S22 E55 32ACAD1 STUMP SPRING WELL & Mapping \\
\hline 355514115453201 & 162 S23 E55 25BACC1 WELL (REPORT R46) & Recreational \\
\hline 360016115361501 & 163 S22 E57 29DABC1 USBLM NDOT 01 & Survey \\
\hline 360310115303201 & 163 S22 E58 07ADDA1 RAINBOW SPRING & Recreational \\
\hline 360255115303301 & 163 S22 E58 07DADA1 BOOTLEG SPRING & Recreational \\
\hline 360126115302201 & 163 S22 E58 20BCAC1 MOUNTAIN SPRINGS & Mapping \\
\hline 355310115305801 & 163 S24 E58 06CDBD1 CAVE SPRING & Recreational \\
\hline 354849115225001 & 164A S24 E59 32DACD1 IVPH-01 & Recreational \\
\hline 354824115182701 & 164A S25 E59 01AADA1 IA JEAN-2 & Recreational \\
\hline 354709115220001 & 164A S25 E59 09DBDA1 JGOLD & Recreational \\
\hline 354706115215901 & 164A S25 E59 09DBDA2 GOLDOBS & Recreational \\
\hline 354719115204601 & 164A S25 E59 10ADCA1 JSTATE & Recreational \\
\hline 354708115212501 & 164A S25 E59 10CBAD1 J4 & Recreational \\
\hline 354557115221001 & 164A S25 E59 16DCCC1 J6E & Recreational \\
\hline 354454115205401 & 164A S25 E59 27AACA1 JAIRPORT & Recreational \\
\hline 352935115103001 & 164B S28 E61 20DBBD1 BULLION SPRING & Recreational \\
\hline 353835115114401 & 165 S26 E61 31ADBB1 NORTH RAILROAD SPRING & Mapping \\
\hline 355015115102601 & 166 S24 E61 20DDAC1 HIDDEN VALLEY & Recreational \\
\hline 355002115100501 & 166 S24 E61 21CCDB1 WELL (REPORT R46) & Recreational \\
\hline 354819115104401 & 166 S25 E61 06AADC1 COX & Recreational \\
\hline 353817114563701 & 167 S26 E63 33CADA1 & Survey \\
\hline 353425115092301 & 167 S27 E61 28ABDA1 PINE SPRING & Recreational \\
\hline 353724115040501 & 167 S27 E62 $05 \quad 1 \quad$ ORA HANNA SPRING & Recreational \\
\hline 353547115033301 & 167 S27 E62 16CBAA1 HIGHLAND SPRING & Mapping \\
\hline 353404115005501 & 167 S27 E62 26DBDA1 COW SPRING & Recreational \\
\hline 353733114553401 & 167 S27 E63 10CCAD1 TENMILE & Recreational \\
\hline 364849114391401 & 205 S13 E66 18BBBB1 FARRIER & Recreational \\
\hline
\end{tabular}


Table 4. National Water Information System wells and springs on Federal land in Clark County, Nevada, surveyed by the U.S. Geological Survey (USGS) with a global positioning system, 2007-2010.-Continued

[Sites with latitude and longitude values from a recreational-grade global positioning system (GPS) survey had altitudes updated from USGS 1:24,000-scale topographic quadrangles]

\begin{tabular}{|c|c|c|}
\hline Site identification number & Station name & Grade of GPS device \\
\hline 364128114343401 & 205 S14 E66 26BDAD1 MOAPA MW-01 & Recreational \\
\hline 365008114541101 & 210 S13 E63 11BACD1 USBLM (Dutch Flat) & Survey \\
\hline 364726114525501 & 210 S13 E63 25BDAA1 WELL (REPORT R25) & Recreational \\
\hline 364728114531001 & 210 S13 E63 25BDBB1 CSVM-1 & Mapping \\
\hline 364738114534001 & 210 S13 E63 26AABD1 CSV-RW-2 & Recreational \\
\hline 364601114514301 & 210 S13 E64 31DADA1 USGS CSV-1 & Survey \\
\hline 364050115103401 & 210 S14 E61 30DDDB1 SAWMILL SPRING & Mapping \\
\hline 364451114585001 & 210 S14 E62 01ADBD1 CSVM-5 & Survey \\
\hline 364116114550301 & 210 S14 E63 27BDCC1 HIDDEN VALLEY - 1 & Recreational \\
\hline 364127114553001 & 210 S14 E63 28AACD1 USGS CSV-3 & Recreational \\
\hline 364119114553201 & 210 S14 E63 28ADCA1 HIDDEN VALLEY - 3 & Recreational \\
\hline 363838115055201 & 210 S15 E61 12BDCD1 MORMON WELL & Recreational \\
\hline 363943114552301 & 210 S15 E63 03BBCC1 CSVM-2 & Recreational \\
\hline 363800115122701 & 212 S15 E60 13BBCD1 WIREGRASS SPRING & Mapping \\
\hline 363332115244001 & 212 S16 E58 14A 1 USFWS DR-1 & Mapping \\
\hline 363212115240301 & 212 S16 E58 23DDD 1 USFWS SBH-1 & Mapping \\
\hline 363501115182601 & 212 S16 E59 02CDBC1 COW CAMP SPRING & Mapping \\
\hline 363407115215301 & 212 S16 E59 082 USGS - Cow Camp & Mapping \\
\hline 363447115182101 & 212 S16 E59 11B 1 RYE PATCH SPRING & Mapping \\
\hline 362750115244001 & 212 S17 E59 20BD 1 USBLM Corn Creek Well & Survey \\
\hline 362620115212601 & 212 S17 E59 34ABBD1 CORN CREEK SPRINGS - S & Survey \\
\hline 362621115212601 & 212 S17 E59 34ABBD2 CORN CREEK SPRINGS - N & Recreational \\
\hline 362610115210701 & 212 S17 E59 34ADAB1 & Recreational \\
\hline 362549115123601 & 212 S17 E60 36DABD1 WHITE SPOT SPRING & Mapping \\
\hline 362706115083101 & 212 S17 E61 22DDBC1 QUAIL SPRING & Recreational \\
\hline 362530115095501 & 212 S17 E61 33CDCD1 GASS SPRING & Recreational \\
\hline 362454115270201 & 212 S18 E58 02BDC $1 \quad$ LSC-01 & Survey \\
\hline 362026115300501 & 212 S18 E58 32DBCC1 GRASSY SPRING & Recreational \\
\hline 362030115293501 & 212 S18 E58 33CBCB1 SHOEMAKER SPRING & Recreational \\
\hline 381913115404201 & 212 S19 E56 03DCCB1 EDNA GREY SPRING & Recreational \\
\hline 361811115404401 & 212 S19 E56 15ABBD1 & Recreational \\
\hline 361617115382001 & 212 S19 E56 25ACAA1 STANLEY B SPRINGS & Recreational \\
\hline 361614115381801 & 212 S19 E56 25ADBD1 & Recreational \\
\hline 361555115392901 & 212 S19 E56 26DBDD1 ECHO 3 & Recreational \\
\hline 361827115373701 & 212 S19 E57 07CDAC1 & Recreational \\
\hline 361833115372501 & 212 S19 E57 07D 1 DEER CREEK SPRING & Recreational \\
\hline 361626115373301 & 212 S19 E57 30BACA1 FLETCHER SPRING & Recreational \\
\hline 361804115292501 & 212 S19 E58 16BCAD1 GRAPEVINE SPRING & Recreational \\
\hline 360941115295101 & 212 S20 E58 32DDDA1 WILLOW SPRING & Recreational \\
\hline 360941115295301 & 212 S20 E58 32DDDA2 WILLOW SPRING WELL & Recreational \\
\hline 361027115284301 & 212 S20 E58 33AAAC1 WHITE ROCK SPRING & Recreational \\
\hline 361027115284001 & 212 S20 E58 33AAAD1 WRS & Recreational \\
\hline 360930115255101 & 212 S21 E58 01ABBA1 ASH CREEK SPRING & Recreational \\
\hline 360922115294901 & 212 S21 E58 04BCAB1 & Recreational \\
\hline 360744115260301 & 212 S21 E58 12DDCC1 VISITORS CENTER & Recreational \\
\hline
\end{tabular}


Table 4. National Water Information System wells and springs on Federal land in Clark County, Nevada, surveyed by the U.S. Geological Survey (USGS) with a global positioning system, 2007-2010._Continued

[Sites with latitude and longitude values from a recreational-grade global positioning system (GPS) survey had altitudes updated from USGS 1:24,000-scale topographic quadrangles]

\begin{tabular}{|c|c|c|}
\hline Site identification number & Station name & Grade of GPS device \\
\hline 360809115252601 & 212 S21 E58 12DDDD1 RED ROCK WASH & Recreational \\
\hline 360720115255201 & 212 S21 E58 13DBBA1 BLUE DIAMOND HILL & Recreational \\
\hline 360717115293301 & 212 S21 E58 16CBCA1 PINE CREEK SPRING & Recreational \\
\hline 360445115283101 & 212 S21 E58 33ADDC1 FIRST CREEK SPRING & Recreational \\
\hline 360901115252501 & 212 S21 E59 06CBBC1 CALICO SPRING & Recreational \\
\hline 360840115251001 & 212 S21 E59 06CCDD1 RED SPRING & Recreational \\
\hline 360627114581001 & 212 S21 E63 20CABA1 & Recreational \\
\hline 360350115262301 & 212 S22 E58 02ADDC1 LONE WILLOW SPRING & Recreational \\
\hline 360307115271701 & 212 S22 E58 11BCBB1 & Recreational \\
\hline 360318115261001 & 212 S22 E58 12BBBD1 MORMON GREEN SPRINGS & Recreational \\
\hline 360149115265501 & 212 S22 E58 14CDBA1 MUD SPRING NO 1 & Recreational \\
\hline 360130115274001 & 212 S22 E58 22ABAC1 & Recreational \\
\hline 360122115274701 & 212 S22 E58 22ACBB1 & Recreational \\
\hline 360109115273001 & 212 S22 E58 22DABB1 LONE GRAPEVINE SPRING & Recreational \\
\hline 360048115273101 & 212 S22 E58 22DDCB1 & Recreational \\
\hline 360310115250201 & 212 S22 E59 07BBCD1 WHEELER CAMP SPRING & Recreational \\
\hline 360247115224401 & 212 S22 E59 09CBDB1 HUMANE & Recreational \\
\hline 355602115253201 & 212 S23 E58 24CABA1 WILSON TANK & Recreational \\
\hline 355829115150601 & 212 S23 E60 03DBCB1 TORTOISE CENTER & Recreational \\
\hline 355321115221401 & 212 S24 E59 04ACDA1 BIRD SPRING & Recreational \\
\hline 360036114444101 & 213 S22 E65 29CDA 1 PUPFISH COLD & Recreational \\
\hline 360036114444102 & 213 S22 E65 29CDA 2 PUPFISH HOT & Recreational \\
\hline 355956114444401 & 213 S22 E65 32CAAC1 & Recreational \\
\hline 355919114444301 & 213 S23 E65 05BDAB1 & Recreational \\
\hline 355621114440101 & 213 S23 E65 21CBC 1 & Recreational \\
\hline 355050114432201 & 213 S24 E65 22BCBA1 & Recreational \\
\hline 354337114490901 & 213 S25 E64 34DBAB1 BRIDGE SPRING & Recreational \\
\hline 352850114474301 & 213 S28 E64 26ADDC1 PHOENIX & Recreational \\
\hline 352818114511201 & 213 S28 E64 32ABAB1 BOAT TANK SPRINGS & Recreational \\
\hline 351741114442001 & 213 S30 E65 33BDAB1 JE-1 & Recreational \\
\hline 352855115070201 & 214 S28 E61 26ADAC1 BURRO SPRINGS & Recreational \\
\hline 352805115061701 & 214 S28 E61 36CAAB1 CLARKS WELL & Recreational \\
\hline 353034115031901 & 214 S28 E62 16BDCB1 LITTLE & Recreational \\
\hline 352924115032101 & 214 S28 E62 22CCAD1 YKL 1 & Recreational \\
\hline 352918115022901 & 214 S28 E62 22CCCA1 WALKING BOX & Recreational \\
\hline 352924115001701 & 214 S28 E62 24CCAB1 PVE-C II & Recreational \\
\hline 352825115012901 & 214 S28 E62 26CCCB1 PVE-G & Recreational \\
\hline 352919114551301 & 214 S28 E63 27ABAB1 S-1 & Recreational \\
\hline 352825114581901 & 214 S28 E63 29CCC 1 BREWER & Recreational \\
\hline 352827114581101 & 214 S28 E63 29CCDB1 GEM-1 & Recreational \\
\hline 352824114582401 & 214 S28 E63 30DDDC1 GEM-2 & Recreational \\
\hline 352743114591901 & 214 S28 E63 31CBCC1 S-2 & Recreational \\
\hline 352715115000801 & 214 S29 E62 01BDAA1 PVE-K & Recreational \\
\hline 352718115015001 & 214 S29 E62 03AADC1 PVE-HI & Recreational \\
\hline 352601114585601 & 214 S29 E63 07DBDB1 SIXMILE & Recreational \\
\hline
\end{tabular}


Table 4. National Water Information System wells and springs on Federal land in Clark County, Nevada, surveyed by the U.S. Geological Survey (USGS) with a global positioning system, 2007-2010.-Continued

[Sites with latitude and longitude values from a recreational-grade global positioning system (GPS) survey had altitudes updated from USGS 1:24,000-scale topographic quadrangles]

\begin{tabular}{|c|c|c|}
\hline Site identification number & Station name & Grade of GPS device \\
\hline 352047114563302 & 214 S30 E63 09DADB1 TENMILE WELL & Recreational \\
\hline 352047114563301 & 214 S30 E63 09DADB2 YKL 2 & Recreational \\
\hline 352217114511401 & 214 S30 E64 05AACA1 DEEP & Recreational \\
\hline 351726114454401 & 214 S30 E65 31DAAC1 THOMAS & Recreational \\
\hline 351508114520501 & 214 S31 E64 17BBCA1 NDOT & Recreational \\
\hline 351701114460001 & 214 S31 E65 06AABA1 BATTLE AXE & Recreational \\
\hline 362633114242101 & 215 S17 E68 20ADAD1 & Recreational \\
\hline 362633114242001 & 215 S17 E68 21BCBB1 GETCHEL SPRING & Recreational \\
\hline 362428114254601 & 215 S17 E68 31DBDD1 & Recreational \\
\hline 362239114263501 & 215 S18 E67 12DDAD1 ROGERS SPRING & Mapping \\
\hline 362230114265501 & 215 S18 E67 13ABAB1 & Recreational \\
\hline 362135114285401 & 215 S18 E67 22AABC1 RB-01 & Survey \\
\hline 362404114240101 & 215 S18 E68 04BACC1 & Recreational \\
\hline 362321114252601 & 215 S18 E68 07ABBA1 BLUE POINT SPRING & Recreational \\
\hline 362259114255201 & 215 S18 E68 07ACCC1 & Recreational \\
\hline 361707114304801 & 215 S19 E67 16BBCC1 BITTER SPRING & Recreational \\
\hline 361229114544001 & 215 S20 E63 14CADB1 GYPSUM SPRING & Mapping \\
\hline 361403114510001 & 215 S20 E64 05DDCA1 & Recreational \\
\hline 361335114463001 & 215 S20 E65 07BCBC1 ROSEN OIL & Recreational \\
\hline 361158114383301 & 215 S20 E66 20BAAA1 COTTONWOOD SPRING & Recreational \\
\hline 361240114332001 & 215 S20 E66H18BDCC1 SANDSTONE SPRING & Mapping \\
\hline 360730114434401 & 215 S21 E65 16CDCB1 WBC & Recreational \\
\hline 360219114475901 & 215 S22 E64 14CDB 1 & Recreational \\
\hline 362753114541001 & 216 S17 E63 14DDDC1 Dry Lake - 2 & Recreational \\
\hline 362700114564401 & 216 S17 E63 21DCCC1 HV-1 & Recreational \\
\hline 362846114495501 & 216 S17 E64 09DDCD1 CRYSTAL 2 & Recreational \\
\hline 362726114523701 & 216 S17 E64 19BDCD1 Dry Lake - 1 & Recreational \\
\hline 362814114505301 & 216 S17 E64 21CBDB1 SP, LA, \& SL RR & Recreational \\
\hline 362717114504901 & 216 S17 E64 21CBDB2 DRY LAKE UPRR EAST & Recreational \\
\hline 362712114504501 & 216 S17 E64 21CCAB1 GARNET & Recreational \\
\hline 362258114550001 & 216 S18 E63 14CBAC2 GRACE WATER & Recreational \\
\hline 363308114553001 & 217 S16 E63 09DDAB1 USBLM SHV-1 & Recreational \\
\hline 362912114422901 & 218 S17 E65 10ADCD1 EAGLE & Survey \\
\hline 362732114435301 & 218 S17 E65 21ACBC1 NV SR169 & Survey \\
\hline 362529114455101 & 218 S17 E65 31DBDD1 WEST & Survey \\
\hline 362136114465001 & 218 S18 E64 25AACC1 MUDDY MOUNTAIN & Recreational \\
\hline 362352114414501 & 218 S18 E65 11DBBC1 BUFPKTS-01 & Survey \\
\hline 362310114461601 & 218 S18 E65 18CC 1 WELL (REPORT R50) & Recreational \\
\hline 364604114471301 & 219 S13 E64 35ACAA1 USGS-MX CE-DT-6 & Recreational \\
\hline 364650114432001 & 219 S13 E65 28BDAC1 USGS CSV-2 & Recreational \\
\hline 364529114492401 & 219 S13HE64 33DBBC1 UMVM-1 & Recreational \\
\hline 364253114430802 & 219 S14 E65 16DBCD1 & Recreational \\
\hline 364251114430401 & 219 S14 E65 16DCB 2 MUDDY RIVER SPRINGS 17 & Recreational \\
\hline 364234114425201 & 219 S14 E65 16DDDC1 USFWS WARM SPRINGS WEST & Recreational \\
\hline 364204114454501 & 219 S14 E65 19CBDB1 BW-1 & Mapping \\
\hline
\end{tabular}




\section{Site-Characteristic and Hydrologic Data for Selected Wells and Springs on Federal Land in Clark County, Nevada}

Table 4. National Water Information System wells and springs on Federal land in Clark County, Nevada, surveyed by the U.S. Geological Survey (USGS) with a global positioning system, 2007-2010.-Continued

[Sites with latitude and longitude values from a recreational-grade global positioning system (GPS) survey had altitudes updated from USGS 1:24,000-scale topographic quadrangles]

\begin{tabular}{|c|c|c|}
\hline Site identification number & Station name & Grade of GPS device \\
\hline 364236114424301 & 219 S14 E65 21AAAA1 WARM SPRINGS EAST & Recreational \\
\hline 364238114424601 & 219 S14 E65 21AAAA4 & Recreational \\
\hline 364237114424501 & 219 S14 E65 21AAAA5 & Recreational \\
\hline 364237114424402 & 219 S14 E65 21AAAA6 & Recreational \\
\hline 364236114424701 & 219 S14 E65 21AAAB2 & Recreational \\
\hline 364235114425201 & 219 S14 E65 21AABB1 MUDDY RIVER SPRINGS 11 & Recreational \\
\hline 364237114425401 & 219 S14 E65 21AABB4 MUDDY RIVER SPRINGS 12 & Recreational \\
\hline 364235114425301 & 219 S14 E65 21AABB5 MUDDY RIVER SPRINGS 19 & Recreational \\
\hline 364223114430101 & 219 S14 E65 21ACAA1 EH-4 & Recreational \\
\hline 362910114280401 & 220 S17 E67 02ACAB1 SPRING (REPORT R50) & Recreational \\
\hline 364353114125501 & 222 S14 E70 07CB 1 NOBLE & Recreational \\
\hline 363842114105401 & 222 S15 E70 09BCDC1 GOVERNMENT SPRING & Recreational \\
\hline 363731114100401 & 222 S15 E70 16DDAC1 NORTH KEY WEST SPRING & Recreational \\
\hline 363707114102301 & 222 S15 E70 21ACBA1 SOUTH KEY WEST SPRING & Recreational \\
\hline 362738114123601 & 223 S17 E70 18AADB1 RED ROCK SPRINGS & Recreational \\
\hline 361544114181801 & 223 S19 E69 20DCB 1 MAYNARD SPRING & Recreational \\
\hline 361545114173301 & 223 S19 E69 21CDBB1 MOCKINGBIRD SPRING & Recreational \\
\hline 361447114183201 & 223 S19 E69 29CDDB1 AGUA CHIQUITA SPRING & Recreational \\
\hline 361658118112501 & 223 S19 E70 17ADDD1 GRANITE SPRING & Recreational \\
\hline 361342114190201 & 223 S20 E69 06ABCD1 CATARACT SPRING & Mapping \\
\hline 361056114173201 & 223 S20 E69 21BDC 1 WALKER SPRING & Recreational \\
\hline 361135114073701 & 223 S20 E70 13CADA1 COTTONWOOD SPRING & Recreational \\
\hline 362111114082501 & 224 S18 E70 23AAAD1 REDI & Recreational \\
\hline 362056114074501 & 224 S18 E70 24CDCA1 HORSE SPRING & Recreational \\
\hline 361804114084701 & 224 S19 E70 11BACA1 GARDEN SPRING WELL & Mapping \\
\hline 361448114055201 & 224 S19 E71 29CCDB1 NEW SPRING & Recreational \\
\hline 361428114062201 & 224 S19 E71 31ACAA1 CONNOLY SPRING & Recreational \\
\hline 09419547 & Blue Point Spr nr Vly of Fire State Park, NV & Mapping \\
\hline 09419625 & CORN CK SPGS AT NATIONAL FISH \& WILDLIFE HDQRS, NV & Recreational \\
\hline 09415908 & PEDERSON E SPGS NR MOAPA, NV & Recreational \\
\hline 09415910 & PEDERSON SPGS NR MOAPA, NV & Survey \\
\hline 09419550 & Rogers Spring nr Overton Beach, NV & Recreational \\
\hline 09419669 & UNNAMED SEEPS ABV LA MADRE SPG NR BLUE DIAMOND, NV & Mapping \\
\hline 09415920 & WARM SPGS W NR MOAPA, NV & Recreational \\
\hline
\end{tabular}


Table 5. National Water Information System wells and springs on Federal land in Clark County, Nevada, for which water samples were collected and analyzed by the U.S. Geological Survey for this and other Southern Nevada Public Land Management Act projects, 2007-2010.

\begin{tabular}{|c|c|c|}
\hline Site identification number & Station name & Number of analyses \\
\hline 363238115464601 & 161 S16 E55 $22 \quad 1$ Army 3 & 1 \\
\hline 363436115432201 & 161 S16 E55H12BCAB1 CACTUS SPRING & 3 \\
\hline 362500115464701 & 161 S18 E55 02ACAD1 WILLOW SPRING & 3 \\
\hline 362108115444201 & 162 S18 E55 25DDCB1 WOOD SPRING & 1 \\
\hline 361541115415001 & 162 S19 E56 28DCCD1 PEAK SPRING & 3 \\
\hline 360459115391101 & 162 S21 E56 36BCBB1 LOST CABIN SPRING & 3 \\
\hline 355941115490901 & 162 S22 E55 32ACAD1 STUMP SPRING WELL & 2 \\
\hline 360126115302201 & 163 S22 E58 20BCAC1 MOUNTAIN SPRINGS & 2 \\
\hline 354719115204601 & 164A S25 E59 10ADCA1 JSTATE & 1 \\
\hline 364050115103401 & 210 S14 E61 30DDDB1 SAWMILL SPRING & 2 \\
\hline 364127114553001 & 210 S14 E63 28AACD1 USGS CSV-3 & 2 \\
\hline 363800115122701 & 212 S15 E60 13BBCD1 WIREGRASS SPRING & 3 \\
\hline 363332115244001 & 212 S16 E58 14A 1 USFWS DR-1 & 1 \\
\hline 362750115244001 & 212 S17 E59 20BD 1 USBLM Corn Creek Well & 1 \\
\hline 362549115123601 & 212 S17 E60 36DABD1 WHITE SPOT SPRING & 3 \\
\hline 362454115270201 & 212 S18 E58 02BDC 1 LSC-01 & 1 \\
\hline 360332115254501 & 212 S22 E58 01CDAD1 OLIVER RANCH 2 & 2 \\
\hline 355321115221401 & 212 S24 E59 04ACDA1 BIRD SPRING & 2 \\
\hline 355919114444301 & 213 S23 E65 05BDAB1 & 1 \\
\hline 355902114444801 & 213 S23 E65 05CAB 1 & 2 \\
\hline 355902114444802 & 213 S23 E65 05CAB 2 & 2 \\
\hline 355756114443401 & 213 S23 E65 08CDD 1 & 2 \\
\hline 355621114440101 & 213 S23 E65 21CBC 1 & 2 \\
\hline 355050114432201 & 213 S24 E65 22BCBA1 & 2 \\
\hline 351712114441201 & 213 S30 E65 33CDAD1 JE-2 & 2 \\
\hline 351009114404201 & 213 S32 E65 12DDCB1 HIKO SPRINGS & 3 \\
\hline 352918115022901 & 214 S28 E62 22CCCA1 WALKING BOX & 2 \\
\hline 352743114591901 & 214 S28 E63 31CBCC1 S-2 & 2 \\
\hline 362239114263501 & 215 S18 E67 12DDAD1 ROGERS SPRING & 3 \\
\hline 361229114544001 & 215 S20 E63 14CADB1 GYPSUM SPRING & 3 \\
\hline 361240114332001 & 215 S20 E66H18BDCC1 SANDSTONE SPRING & 3 \\
\hline 364253114430802 & 219 S14 E65 16DBCD1 & 3 \\
\hline 364204114454501 & 219 S14 E65 19CBDB1 BW-1 & 1 \\
\hline 364236114424701 & 219 S14 E65 21AAAB2 & 3 \\
\hline
\end{tabular}


14 Site-Characteristic and Hydrologic Data for Selected Wells and Springs on Federal Land in Clark County, Nevada

Table 5. National Water Information System wells and springs on Federal land in Clark County, Nevada, for which water samples were collected and analyzed by the U.S. Geological Survey for this and other Southern Nevada Public Land Management Act projects, 2007-2010.-Continued

\begin{tabular}{|c|c|c|}
\hline Site identification number & Station name & Number of analyses \\
\hline 363842114105401 & 222 S15 E70 09BCDC1 GOVERNMENT SPRING & 2 \\
\hline 362735114154501 & 223 S17 E69 14ABB 1 RED BLUFF SPRING & 3 \\
\hline 361804114084701 & 224 S19 E70 11BACA1 GARDEN SPRING WELL & 2 \\
\hline 361448114055201 & 224 S19 E71 29CCDB1 NEW SPRING & 2 \\
\hline 09419669 & UNNAMED SEEPS ABV LA MADRE SPG NR BLUE DIAMOND, NV & 3 \\
\hline
\end{tabular}




\section{References Cited}

Buchanan, T.J., and Somers, W.P., 1969, Discharge measurements at gaging stations: U.S. Geological Survey Techniques of Water-Resources Investigations, book 3, chap. A8, $65 \mathrm{p}$.

Cardinalli, J.L., Roach, L.M., Rush, F.E., and Vasey, B.J., 1968, State of Nevada hydrographic areas: Nevada Division of Water Resources map, scale 1:500,000.

Crafford, A.E.J., 2007, Geologic map of Nevada: U.S. Geological Survey Data Series 249, 1 CD-ROM, 46 p., 1 plate., http://pubs.er.usgs.gov/publication/ds249.

Cunningham, W.L., and Schalk, C.W., comps., 2011, Groundwater technical procedures of the U.S. Geological Survey: U.S. Geological Survey Techniques and Methods 1-A1, 151 p. Available only online at http://pubs.usgs.gov/tm/lall.

Esri, 2008, U.S. USGS 1:24,000 Topographic Quadrangle Series Indexes: ESRI Data \& Maps CD.

Esri, 2013, World Imagery online map service, accessed April 24, 2013, at http://services.arcgisonline.com/ArcGIS/rest/ services/World_Imagery/MapServer.

Fenneman, Nevin M., and Johnson, Douglas W., 1946, Physical divisions of the United States: U.S. Geological Survey Special Map, scale 1:7,000,000.

Glancy, P.A., 1968, Water-resources appraisal of MesquiteIvanpah Valley area, Nevada and California: Nevada Department of Conservation and Natural Resources Ground-Water Resources Reconnaissance Series Report 46, 57 p., 1 plate.

Harrill, J.R., Gates, J.S., and Thomas, J.M., 1988, Major ground-water flow systems in the Great Basin region of Nevada, Utah, and adjacent states: U.S. Geological Survey Hydrologic Atlas 694-C, 6 maps on 2 sheets.

Laczniak, R.J., Cole, J.C., Sawyer, D.A., and Trudeau, D.A., 1996, Summary of hydrogeologic controls on ground-water flow at the Nevada Test Site, Nye County, Nevada: U.S. Geological Survey Water-Resources Investigations Report 96-4109, 59 p.

McKinley, P.W., Long, M.P., and Benson, L.V., 1991, Chemical analyses of water from selected wells and springs in the Yucca Mountain area, Nevada and southeastern California: U.S. Geological Survey Open-File Report 90-355, 47 p., $1 \mathrm{pl}$.
Nevada Division of Water Resources, 2013, Well log database query tool, accessed June 1, 2013, at http://www.water. nv.gov/data/welllog/index.cfm.

Peltz, L., Medina, R., and Buto, S., 2005, 1:750,000-scale hydrographic areas and basin-wide pumpage, recharge, and interbasin flow estimates of Nevada: U.S. Geological Su vey online dataset, accessed April 24, 2013, at http://water. usgs.gov/GIS/metadata/usgswrd/XML/nv_ha750nv.xml.

Rantz, S.E., and others, 1982, Measurement and computation of streamflow: Volume 1, Measurement of stage and discharge: U.S. Geological Survey Water Supply Paper 2175, $284 \mathrm{p}$.

Rush, F.E., 1968, Index of hydrographic areas in Nevada: Nevada Division of Water Resources Information Report 6, $38 \mathrm{p}$.

Steeves, P., and Nebert, D., 1994, 1:250,000-scale Hydrologic Units of the United States: U.S. Geological Survey OpenFile Report 94-0236, unpaged, accessed April 24, 2013, at http://water.usgs.gov/GIS/metadata/usgswrd/XML/huc250k. xml.

U.S. Bureau of Land Management, 2013a, Southern Nevada Public Land Management Act (SNPLMA), accessed June 11, 2013, at http://www.blm.gov/nv/st/en/snplma.html.

U.S. Bureau of Land Management, 2013b, Download Public Land Survey System (PLSS) Data, accessed April 24, 2013, at http://www.geocommunicator.gov/GeoComm/lsis_home/ homel.

U.S. Bureau of Land Management, 2013c, Public Land Survey System online map service, accessed April 24, 2013, at http://www.geocommunicator.gov/ArcGIS/rest/services/ PLSS/MapServer.

U.S. Census Bureau, 2007, TIGER/Line shapefile, 2007, state of Nevada, county and equivalent: U.S. Census Bureau online dataset, accessed April 24, 2013, at http://www. census.gov/geo/maps-data/data/tiger-line.html.

U.S. Census Bureau, 2013, Census of population and housing, accessed June 11, 2013, at http://www.census.gov/prod/ www/decennial.html.

U.S. Geological Survey, variously dated, National field ma ual for the collection of water-quality data: U.S. Geological Survey Techniques of Water-Resources Investigations, book 9, chaps. A1-A9, at http://pubs.water.usgs.gov/twri9A. 
U.S. Geological Survey, 1998, National Water Information System (NWIS): U.S. Geological Survey Fact Sheet 027-98, at http://pubs.er.usgs.gov/publication/fs02798.

U.S. Geological Survey, 2005, National atlas-principal aquifers of the 48 conterminous United States, Hawaii, Puerto Rico, and the U.S. Virgin Islands, accessed April 24, 2013, at http://nationalatlas.gov/mld/aquifrp.html.

U.S. Geological Survey, 2013a, Hydrography, accessed January 18, 2013, at http://nhd.usgs.gov/index.html.

U.S. Geological Survey, 2013b National Water Information System data available on the World Wide Web (USGS Water Data for the Nation), accessed January 18, 2013, at http://waterdata.usgs.gov/nwis/. 


\section{Appendix 1. Selected data stored in the U.S. Geological Survey National Water Information System for selected wells and springs on Federal Land in Clark County, Nevada.}

The Microsoft Excel workbook (http://pubs.usgs.gov/ds/864) presents National Water Information System (NWIS) data and links to NWIS data for project area sites. Appendix 1-1 presents NWIS site identification numbers, station names, and links $\mathrm{t}$ the NWIS web interface (NWISWeb) for project-area sites.
Water-level, spring-discharge, and water-chemistry data are available from NWISWeb. Appendixes 1-2 - 1-17 present NWIS site-characteristic data reviewed for this project that are not available from NWISWeb; the data were retrieved from June 28 to July 1, 2013.

\section{Appendix 2. Publications reviewed for site-characteristic and hydrologic data for selected wells and springs on Federal Land in Clark County, Nevada.}

The Microsoft Excel workbook (http://pubs.usgs.gov/ds/864) presents citations for publications and reports reviewed for this project. Appendix 2-1 presents citations for publications and reports that have site-characteristic or hydrologic data stored in National Water Information System (NWIS) for projectarea sites. Appendix 2-2 presents citations for publications and reports that were researched but do not have site-characteristic or hydrologic data for sites in the project area. 

